\title{
IMPLEMENTATION OF CSR IN BENGKULU AFTER THE ISSUANCE OF THE BENGKULU GOVERNOR'S DECREE NUMBER: P.127.DINSOS. OF 2018 CONCERNING THE ESTABLISHMENT OF THE CSR FORUM OF BENGKULU PROVINCE
}

By :

\author{
Difo Pradipta, Slamet Mulyono, Emelia Kontesa
}

\begin{abstract}
CSR is an element in improving people's welfare. Through the establishment of a CSR Forum which was established based on the Bengkulu Governor's Decree Number: P.127.Dinsos. In 2018 concerning the Establishment of the Bengkulu Province CSR Forum, the Regional Government seeks to increase the participation of every company in Bengkulu. However, the results have not been effective, this is because the formation of this forum was not accompanied by the authority and mechanism in the form of a Governor Regulation. The impact is that CSR implementation in Bengkulu Province is small and not focused. The problem in this research is how the implementation of CSR after the issuance of the Bengkulu Governor's Decree Number: P.127.Dinsos. 2018 concerning the Establishment of the Bengkulu Province CSR Forum and What Are the Obstacles in the implementation of the CSR forum. This type of research is empirical, data sources obtained from interviews, documents, as well as literature and legislation relevant to the research. The result of this research is the finding of a $16 \%$ percentage of the participation rate of companies in Bengkulu, from a total of 196 companies in Bengkulu, only 33 companies registered by the CSR Forum have distributed CSR. The rest of this company never reported the distribution of CSR. This is very inconsistent with the Utilities Theory because large companies in Bengkulu Province have not contributed too much to the Environment and Society, and are still focused on Company Profits only. Furthermore, in the second discussion it was also conveyed that several obstacles were experienced by the CSR Forum, among others: The government has not yet embraced the forum in relation to companies, There is no Regulation on Implementation Mechanism in the Investment Law and the TDP Law, the Report Submission Mechanism is not Clearly, the absence of basic technical rules for implementing CSR reporting, absence of punishments and sanctions from the local government to companies for distributing CSR.
\end{abstract}

Keywords: CSR, Authority, Bengkulu Province CSR Forum. 


\section{A. INTRODUCTION}

\section{Background Research}

The term CSR enteredIndonesia starting in the 1980s, but its popularity only emerged in 1990 where this term appeared after the activity had taken place. Various social activities that have been carried out in 1990, such as assistance to the victims of natural disasters, scholarships, holiday allowances, assistance for the poor, and scholarships. CSR development in Indonesia is similar to other countries. At that time, it has not had a guide and a legal basis, it a form of care only.

When the ISO 26000 began inaugurated in 2010 , one by one of the country began to implement these guidelines, for Indonesia itself, the link between CSR and the Company has existed since the first in the Constitution of the State of Republic of Indonesia Year 1945, namely Article 33, paragraph 3, which reads: "The earth, water and natural resources contained therein shall be controlled by the State and used for the greatest prosperity of the people: " The land, the waters, and the natural resources within shall be under thepowers of the
State and shall be used to the greatest benefit of the people"

This article implies that the welfare of the Indonesian people is not solely the responsibility of one party, but the responsibility of all interested parties (stakeholders) such as the state and entrepreneurs who enjoy the wealth of the Republic of Indonesia, a form of entrepreneurial responsibility towards society. is a corporate social responsibility known as "Corporate Social Responsibility (CSR).

Besides the company, the meaning of the word powered by the state can also mean used by the state. Therefore, the ownership and control by the state over natural resources, as a consequence of state interference in the socio-economy of citizens and the state's obligation to create general welfare and prosperity for the people, can be formed by implementing policies on CSR.

Juridically, there are many legal bases regarding CSR or Corporate Social Responsibility, but in the implementation of CSR, there are still obstacles related to regulations and monitoring 
instruments, whether it is distributed or not, and how much CSR is distributed cannot be monitored optimally.

The absence of the appropriate authorities to control directly resulted in the Company becoming sometimes do not care and just do it sober whereas CSR companies investing or doing business in an area are required and are responsible for the implementation of CSR in the Act.

According to the writer, the implementation of the CSR of the companies in the sector above has not been optimally implemented in Bengkulu Province. Ideally, the implementation of this CSR is right on target and carried out optimally, of course, it can help the economy in Bengkulu Province. But in fact, this has not been done. Despite the efforts made by the Local Government of Bengkulu Province in optimizing CSR by creating a Forum called the Bengkulu Province CSR Forum (based on the Governor's Decree Number: P.127.Dinsos of 2018 concerning the Establishment of the Social Responsibility Forum for Business Entities in the Social
Implementation of Bengkulu Province in the service period of 2018-2023) but the results have not yet been seen.

The existence of this forum itself has not been supported by the existence of a regulated mechanism and authority, therefore, the principle of the usefulness of the establishment of this forum cannot be fully applicable. The forum which should become a forum to facilitate companies in distributing CSR, was not optimal because there was no coordination and full support from the Local Government of Bengkulu Provinceas the founder.

\section{Identification of Problems}

1. How is the Implementation of CSR in Bengkulu after the issuance of the Bengkulu Governor's Decree Number: P.127.Dinsos. of 2018 concerning the Establishment of the CSR Forum of Bengkulu Province?

2. What are the obstacles or constraints in implementing the CSR Forum? 


\section{Research Objectives:}

1. To find out about the implementation of CSR after the issuance of the Bengkulu Governor's Decree Number: P.127.Dinsos. in 2018 concerning the Establishment of the CSR Forum

2. To find out what actions and efforts the Government can take to improve the Company's compliance in CSR distribution in Bengkulu Province.

\section{B. RESEARCH METHODS}

The type of research used in this research was Empirical that describes a condition at this time in accordance with what is happening.

The nature of this research was analytical descriptive, namely research that describes (provides a picture) or a clear explanation of the facts or symptoms that are the object of research and analyzes the findings obtained, the intention is mainly to reinforce hypotheses so that it can help in strengthening theories old, or within the framework of developing a new theory. ${ }^{1}$
This study was aimed to find out the relationship between 2 symptoms that provide a systematic, factual, and accurate picture of the facts in the field. ${ }^{2}$ relying on the juridical aspect so that it will answer the problems that become the object of research, namely regarding the Implementation of Bengkulu Governor Decree Number: P.127.Dinsos. in 2018 concerning the Establishment of a CSR Forum as an Effort to Control Local Government in the Distribution of CSR in Bengkulu.In this case, the respondents of this study are the Chairperson $\&$ the Secretary of the Bengkulu Province CSR Forum, Head of the Corporate Secretary Division of PT. Bank Bengkulu, Public Relations Division of Bank Indonesia, Head of Social Service of Bengkulu Province, Head of Trade Division of Industry and Trade Service, Head of Section for Development of Solidarity Potential and Social Restoration of Bengkulu Province Social Service. Secondary data sources are secondary data, which are data obtained from library research by conducting library research which aims to find data in the form of theories, opinions, views,
Soerjono Soekanto, 1986, Pengantar Penelitian Hukum, University of Indonesia (UIPress), Jakarta, p. 10
${ }^{2}$ Ibid, p. 96 
which are closely related to the subject matter under study. ${ }^{3}$

\section{RESULTS AND DISCUSSION}

\section{Implementation of CSR in}

Bengkulu after the issuance of the

Bengkulu Governor's Decree

Number: P.127.Dinsos. of 2018 concerning the Establishment of the CSR Forum of Bengkulu

\section{Province}

CSR in Indonesia issomething newthat has emerged since the 1980s but only became popular among the community in the 2000s. For Bengkulu Province itself, the term CSR began when the management of the first Social Responsibility Forum was formed through the Governor's Decree Number: L.133.XIII of 2013 concerning the period of service for the management of the Business World Social Responsibility Forum in the implementation of social welfare in Bengkulu Province.

During 5 years because of the busyness of each member who is the leader in their respective agencies, then this forum never produced any results, so it can be said that the management of this forum at that time just a name without any activity that could increase CSR more meaningfully.

Even though, the main duties and functions which were formed in 2014, which in Article 16 of Local Regulation Number 1 of 2014 concerning Corporate Social Responsibility reads:

\section{Article 16}

(1) Local governments submit priority-scale programs as material in CSR program planning to the TSP implementing forum.

In this article, it is clear that the basic philosophy of the establishment of this Corporate Social Responsibility Forum is to convey the priority scale of the Government whether to distribute this TJSL for development or other aspects such as economic and social.

Such plans can not see at the time of the establishment of the CSR Forum in 2013, due to lack of coordination and Plan of Action of the TJSLForum. The intensity of the meetings is very rarely carried out so that the vision that was planned at the beginning of the inauguration of the forum did not work as it should.

After the end of the old CSR forum management in 2018, the Governor of Bengkulu appointed the

\footnotetext{
${ }^{3}$ Ibid, p. 26
} 
management of this new CSR Forum chaired by Mr. Fery Rizal who is also the Chair of the Indonesian Chamber Of Commerce \& Industry (KADIN) of Bengkulu.

Under the management of Mr. Feri Rizal, the CSR forum finally began to carry out its proper activities, one of which was a meeting of companies in Bengkulu Province facilitated by the Social Service as the Person in Charge of this CSR Forum.

In the development of this forum, since its formation through a new Governor's Decree in 2018, the number of participants has increased to 33 companies from previously none in the 2013-2018 period. The progress of these participants can be seen from the submission of the annual CSR Disbursement report provided by the Company to the Bengkulu Province CSR Forum.

However, if talk about the percentage, this number is still relatively small, because the company data recorded in the OSS system of DPMPTSP Office records that there are 196 companies in Bengkulu, meaning that 33 companies are only $16 \%$ or $1 / 6$ of the total companies.
This unfavorable result was triggered by several things, namely, the number of operational costs provided by the Social Service of Bengkulu Province itself was relatively small, only 12 million rupiahs for one year. ${ }^{4}$ This amount is certainly far from feasible, assuming that only one employee in correspondence and administration in the Forum for 1 year is only 1 million per month, this is of course under the UMR and also management operational costs cannot be supported.

However, behind the limited funds, as the supervisor of CSR Forum of Bengkulu Province, the Social Service of Bengkulu Province has also taken several strategic steps to encourage the Company's activeness in distributing CSR. Some of these steps include:

1. Outreach activities through the media

Socialization in local media has been carried out to encourage corporate activity. For example, on Radio RRI, local television such as RB TV, etc.

${ }^{4}$ Attachment to the Decree of the Head of Social Service Number 220/158 / Dinsos-IV / 2020 
2. Coordination of Business world potential meeting activity

\section{Strengthening} the potential of the business world

4. Operational assistance for the social welfare of CSR forum

These steps are all carried out in hope that this Forum can run properly and perform optimally therefore the Social Welfare of the Provincial community can increase with the support of the Corporate Social Fund in Bengkulu Province.

\section{OBSTACLES AND PROBLEMS} IN DISTRIBUTION OF CSR

CSR distribution is an important aspect of the sustainability of the community around the company. Seen from the legal aspect, many regulations have been issued by the Government in making this distribution work effectively. Regulations that are formed starting from laws that specifically regulate such as the Minerba Law, up to local regulations, or in a Governor's Decree form.

CSR in Bengkulu Province itself has been channeled by companies to various sectors ranging from Education, Social, Religion,
Tourism, etc. The CSR distribution data obtained by the writer from CSR Forum of the Bengkulu Province illustrates that the distribution of CSR itself has been carried out by severallarge companies. However, if seen at the number of PT as a whole in Bengkulu Province, the number of 33 companies is very small.

There are several problems which in the opinion of the writer cause delays in the distribution of CSR in Bengkulu Province, are as follows:

1. Lack of communication between the Government and the Company

The writer himself has made observations to agencies such as the Industry and Trade Service, but when talking about group representatives in a Whatsapp group, the relevant office cannot provide information about the group even though the data on the number of companies is quite a lot.

2. CSR has not been made a mandatory report item in the company license 
extension at the

Investment and

\section{Integrated One-Stop}

Services Agency.

In the details of the requirements for the extension of the TDP carried out at the DPMPTSP Office, no rule or mechanism of requirements emphasizes that the company must first report CSR. So it is clear that the company does not feel the need to report or even distribute CSR because there is no pressure from the Stakeholders or the Government.

3. The unclear mechanism for submitting annual reports

The mechanism for submitting CSR reports itself is not clearly described, we can see this in the Investment Law Number 25 of 2007 and in the Local Regulation of Bengkulu Province which is its derivative Number 1 of $2014 \quad$ concerning Corporate Social
Responsibility, even though the Annual Report is a reference for the government in seeing the fair value of CSR when compared to the company's profits.

4. The absence of basic technical rules for implementation in CSR reporting.

In the Local Regulation of Bengkulu Province concerning Corporate Social Responsibility and the Governor's Decree regarding the establishment of the TJSL Forum, only contains sanctions and duties. Then how can the sanctions work, if the procedure is not included in the technical regulations, therefore, a Governor's Circular Letter or a revised Local Regulation on CSR is required to implement the CSR Reporting procedure.

5. There are no punishments and sanctions imposed by the 


local government on
companies for
distributing CSR.
In-Law Number 25
of 2007 concerning
Investment not regulated
when and to whom this
CSR distribution must be
reported. This is the
responsibility of the
regulation which is the
basis for why there are
still companies that have
not distributed CSR.
Because there is no
reporting period and the
authorized agency requests
it annually.

\section{CLOSING}

\section{Conclusion}

1. The Limited Liability Company Law and the Investment Law as the Laws which become guidelines in implementing CSR have not provided clear regulations regarding CSR Distribution, only written about sanctions while the mechanism has never been made therefore the derivative regulations as contained in local Regulation Number 1 of 2014 concerning
Corporate Social Responsibility also follows the Law which results in a lack of company awareness in conducting this CSR distribution.

In the implementation of the CSR Forum in Bengkulu Province itself resulted in not being able to do much because the Company in its position could not be pressured by the forum because of the absence of authority from this Forum, the implementation of CSR so far has only been an appeal and no coercion or sanction can be applied.

2. Some of the obstacles that arise as a result as described in point one are as follows:

a. Lack of communication between the Government and the Company

b. CSR has not been made a mandatory report item in the company license extension at the Investment and Integrated One-Stop Services Agency

c. The unclear mechanism for submitting annual reports

d. The absence of basic technical rules for implementation in CSR reporting. 
e. There are no punishments and sanctions imposed by the local government on companies for distributing CSR.

\section{Suggestion}

As for what the local government needs to do in increasing participation and distribution of CSR in Bengkulu Province, according to the writer's opinion, are as follows:

1. Local governments need to make a circular letter or governor's decree regarding the technical guidelines for implementation in CSR reportingtherefore CSR implementation can have clear directions and the implementation has a legal basis for action.

2. Include the Mandatory Points for Submitting the Company's Annual Report to the Local Government of Bengkulu Province in the circular letter that will be made, as material for consideration in distributing CSR by looking at the number of Company Profits and Operational Area
Branch Profits in Bengkulu. This is useful for preventing fraud on the published profit value, therefore the Local Government can get a fair value for the distribution of the Company's CSR in Bengkulu Province by obtaining a reference.

3. Write to the Head Office of each company and notify about the Bengkulu Province Regulation and its legal sanctions if the company that invests in Bengkulu Province neglects in providing CSR.

4. Making an additional Governor's Circular Letter or Decree containing additional rules in the extension of the TDP permit, namely Making the CSR Forum the central in terms of extending the Company's TDP permit, where the Company is required to submit a CSR Distribution Report to the forum, and the forum can issue a recommendation in the extension business 
license to the DPMPTSP

Office.

5. Reinforce the penalties for non-compliancecompany in the form of a CSR Implementation Decree to provide a deterrent effect for business actors who are indifferent in distributing CSR. These sanctions can be applied by revoking the Company's TDP license or prohibiting the company's operations before the distribution of CSR.

\section{REFERENCES}

Soerjono Soekanto, 1986, Pengantar Penelitian Hukum, University of Indonesia (UI-Press), Jakarta.

Attachment to the Decree of the Head of Social Service Number 220/158 / Dinsos-IV / 2020 